\title{
Aktivitas Antibakteri Isolat Bakteri Asam Laktat Intestinal Udang Penaeid Tipe Liar Terhadap Bakteri Vibrio
}

\section{Subagiyo'*, Sebastian Margino², Triyanto2, Feri Setiawan², Wilis Ari Setyati1 dan Rini Pramesti ${ }^{1}$}

\author{
'Departemen IImu Kelautan, Fakultas Perikanan dan IImu Kelautan, Universitas Diponegoro \\ JI. Prof. Soedarto, SH. Kampus UNDIP Tembalang, Semarang 50275 \\ 2Fakultas Pertanian, Universitas Gadjah Mada, Yogyakarta, Indonesia \\ Bulaksumur, Yogyakarta 55281 \\ Email: subagiyo.kelautan13@gmail.com
}

\begin{abstract}
Lactic acid bacteria are groups of bacteria that have been commonly used as probiotics with functional targets controlling pathogens. In this study, BAL were isolated from penaeid shrimp intestinum was captured in natural waters and were tested of antibacterial activity against 3 types of pathogenic vibrio bacteria in shrimp. The shrimp samples were taken from the North Coast of Java (Situbondo and Semarang) and the South coast of Java (Cilacap). BAL isolation was done by pour plate method using MRS medium enriched with CaCO3. The antibacterial activity test was performed by using paper diffusion method using $V$. harveyi, $V$. anguilarum and V. parahaemolyticus as bacteria indicator. The isolation result obtained 224 isolates of BAL intestinal of penaeid shrimp. The active BAL isolates against $V$. Harveyi, V. anguilarum and V. parahaemolyticus were 59, 83 and 66 isolates, respectively. Isolates are active against 3 types, 2 types and 1 type of Vibrio were 51,25 and 11 isolates respectively.
\end{abstract}

Keyword : lactic acid bacteria, antibacteria, vibrio, penaeid shrimp

\begin{abstract}
Abstrak
Bakteri asam laktat merupakan kelompok bakteri yang telah banyak digunakan sebagai probiotik dengan target fungsional mengendalikan pathogen. Pada penelitian ini telah dilakukan isolasi BAL dari intestinum udang penaeid yang ditangkap di perairan alam dan pengujian aktivitas antibakteri terhadap 3 jenis bakteri vibrio pathogenik pada udang. Sampel udang diambil dari Pantai Utara Jawa (Situbondo dan Semarang) dan pantai Selatan Jawa (Cilacap). Isolasi BAL dilakukan dengan metode taburan menggunakan medium MRS yang diperkaya dengan $\mathrm{CaCO}_{3}$. Uji aktivitas antibakteri dilakukan dengan paper diffusion method menggunakan bakteri uji $V$. harveyi, $V$. anguilarum dan $V$. parahaemolyticus. Hasil isolasi diperoleh 224 isolat BAL intestinal udang penaeid. Isolat BAL yang aktif terhadap $V$. Harveyi, $V$. anguilarum dan $V$. parahaemolyticus berturut-turut 59, 83 dan 66 isolat. Isolat yang aktif terhadap 3 jenis, 2 jenis dan 1 jenis Vibrio uji berurut-turut 51, 25 dan 11 isolat.
\end{abstract}

Kata Kunci : bakteri asam laktat, antibakteri, vibrio, udang penaeid

\section{PENDAHULUAN}

Vibrio merupakan salah satu agensia penyebab penyakit pada udang. Jenisjenis penyakit vibriosis ini meliputi black shell disease, tail rot, septic hepatopancreatic necrosis, brown gill disease, swollen hindgut syndrome dan luminous bacterial disease (Heenatigala \& Fernando, 2016). Jenis penyakit yang disebabkan oleh Vibrio yang saat ini merupakan penyakit baru dan ganas adalah early mortality syndrome (EMS) atau acute hepatopancreatic necrosis disease (AHPND). Penyakit ini 
ditengarai disebabkan oleh satu atau lebih strain spesifik $V$. parahaemolyticus (De Schryver et al., 2014). Salah satu pendekatan penyakit yang disebabkan oleh vibriosis adalah melalui aplikasi probiotik yang memiliki kemampuan menghambat pertumbuhan Vibrio.

Penelitian probiotik di bidang perikanan jauh tertinggal dibandingkan penelitian di bidang peternakan, industri makanan fungsional dan kesehatan manusia. Peluang yang luas terbuka untuk melakukan kajian di bidang probiotik perikanan pada umumnya dan budidaya udang pada khususnya. Teknologi probiotik sekarang telah diterima oleh para praktisi tambak (Zhou \& Wang, 2003), sehingga perhatian besar ditujukan untuk terus melakukan penelitian di bidang probiotik. Penggunaan probiotik di budidaya perikanan memiliki berbagai target yaitu meningkatkan pertumbuhan, pencernaan nutrien, kualitas air, stress tolerance, reproduksi dan pengendalian patogen (Cruz et al., 2012).

Bakteri asam laktat dipilih untuk dikembangkan sebagai probiotik untuk menyehatkan udang didasarkan pada (1) bakteri asam laktat merupakan mikroorganisme yang secara genetik adalah aman (memiliki status GRAS= genetically recoqnized as safe) (Ljungh \& Wadström, 2006), (2) merupakan bakteri yang umum hidup di dalam intestinum manusia dan hewan, termasuk udang (Maeda et al., 2014), (3) mampu hidup dan melekat di dalam sistem mukosa intestinum (Balcazar et al., 2006 dan Ljungh \& Wadström, 2006), (4) mampu berkompetisi dengan patogen untuk reseptor pelekatan di epitelium intestinum (Balcazar et al., 2006 dan Vesterlund et al., 2006), (5) mampu berkompetisi terhadap nutrien esensial (Balcazar et al., 2006), (6) menghasilkan asam organik, hidrogen peroksida dan bakteriosin yang bersifat antagonis terhadap patogen (Balcazar et al., 2006; Rattanachaikunsopon \& Phumkhachorn, 2010), (7) menghasilkan produk bermanfaat lain seperti enzim ekstraseluler (Bogale et al., 2015 dan Donlora et al., 2007), antioksidan (Ljungh \& Wadström, 2006), (8) meningkatkan sistem imun
(Balcazar et al., 2006 dan Maeda et al., 2014), (9) bersifat noninvasif, nonkarsinogenik dan nonpatogenik (Farzanfar, 2006), (10) memiliki sejarah panjang digunakan sebagai starter produk makanan dan minuman serta probiotik untuk manusia dan ternak. Kinerja BAL sebagai probiotik bersifat multifaktoral yang meliputi pengendalian komunitas mikroflora saluran pencernaan, pengendalian populasi patogen, proteksi infeksi, dan konstribusi proses pencernaan, oleh karena itu eksplorasi bakteri asam laktat sebagai probiotik memiliki nilai strategis tersendiri.

Menurut Kosin \& Rakshit (2006) salah satu kriteria seleksi probiotik adalah kemampuan menghambat pertumbuhan pathogen (memiliki aktivitas antimikrobia). Maka probiotik untuk mengendalikan penyakit Vibriosis harus memiliki aktivitas antibakteri terhadap vibrio. Pada penelitian ini dilaporkan hasil isolasi bakteri asam laktat (BAL) yang memiliki aktivitas antibakteri terhadap Vibrio. Ioslat-siolat ini selanjutnya dapat diseleksi lebih lanjut untuk dikembangkan sebagai konsorsium probiotik utnuk mengendalikan penyakit vibriosis.

\section{MATERI DAN METODE}

Pada penelitian ini BAL diisolasi pada intestinum udang penaeid tipe liar yang ditangkap di periaran Situbondo (Jawa Timur), Semarang dan Cilacap (Jawa Tengah). Vibrio yang digunakan sebagai bakteri uji adalah $V$. harveyi, $V$. anguilarum dan $V$. parahaemolyticus. Vibrio ini diperoleh dari Laboratorium Manajemen Kesehatan Hewan Akuatik, Balai Besar Pengembangan Budidaya Air Payau (BBPBAP) Jepara, Jawa Tengah. Vibrio ditumbuhkan pada medium nutrient agar. Bakteri ini selanjutnya disimpan sebagai stok dalam larutan gliserol (30\%) dan susu skim (10\%) dengan perbandingan 1:1 pada suhu $-80^{\circ} \mathrm{C}$.

Media yang digunakan untuk isolasi adalah medium MRS dengan komposisi media MRS adalah tripton $(10,0 \mathrm{~g} / \mathrm{l})$, ekstrak khamir $(5,0 \mathrm{~g} / \mathrm{l})$, glukosa $(20,0 \mathrm{~g} / \mathrm{l}), \mathrm{K}_{2} \mathrm{HPO}_{4}$ $(2,0 \mathrm{~g} / \mathrm{l})$, sodium asetat $(5,0 \mathrm{~g} / \mathrm{l}), \mathrm{MgSO}_{4}$ 
$7 \mathrm{H}_{2} \mathrm{O} \quad(0,2 \mathrm{~g} / \mathrm{l}), \quad \mathrm{MnSO}_{4}-\mathrm{H}_{2} \mathrm{O} \quad(0,05 \mathrm{~g} / \mathrm{l})$, amonium sulfat $(2,0 \mathrm{~g} / \mathrm{l})$, tween $80(1 \mathrm{ml} / \mathrm{l})$. Media untuk uji aktivitas antivibrio adalah medium Nutrient Agar (NA) dengan komposisi pepton $(10 \mathrm{~g} / \mathrm{l})$ gram dan beef ekstract (3 g/l)

\section{Isolasi BAL}

Udang yang telah dipuasakan selama 2 hari dianestasi dengan suhu rendah. Permukaan tubuh udang disterilisasi menggunakan hipoklorit 10,2 $\mathrm{mg} / \mathrm{l})$. Intestinum diperoleh melalui pembedahan secara aseptik menggunakan peralatan seksio steril. Intestinum kemudian dipotong dan dimasukkan ke dalam cawan petri steril. Sampel intestinum dicuci secara aseptik dalam air laut steril, selanjutnya ditiriskan dan ditimbang sebanyak $1 \mathrm{~g}$. Intestinum dimasukkan ke dalam lumpang porselin dan dihomogenasikan menggunakan penumpuk lumpang. Homogenat diambil dan disuspensikan ke dalam $9 \mathrm{ml}$ air laut steril. Satu $\mathrm{ml}$ suspensi homogenat intestinum diinokulasikan ke dalam $9 \mathrm{ml}$ medium MRS cair. Kultur ini selanjutnya di inkubasi pada suhu kamar selama 48 jam.

Isolasi BAL dilakukan dengan metode taburan. Satu $\mathrm{ml}$ kultur bakteri intestinal diinokulasikan ke dalam $9 \mathrm{ml}$ air laut (70\%) steril untuk mendapatkan faktor pengenceran 10-1. Seri pengenceran 10-2 dibuat dengan menginokulasikan $1 \mathrm{ml}$ suspensi bakteri pada pengenceran $10^{-1} \mathrm{ke}$ $9 \mathrm{ml}$ air laut steril, demikian seterusnya sampai diperoleh seri pengenceran 10-6. Suspensi bakteri pada masing-masing pengenceran secara aseptik diambil sebanyak $100 \mu$ dan dipipetkan ke dalam cawan petri steril, kemudian media MRS agar yang mengandung $\mathrm{CaCO}_{3} 1 \%$ dan $\mathrm{Na}$ azide $0,01 \%$ dalam kondisi telah dicairkan (suhu sekitar $50^{\circ} \mathrm{C}$ ) dituang ke dalam cawan petri dan diratakan. Inkubasi dilakukan secara aerob pada suhu kamar selama 72 jam. Koloni bakteri asam laktat ditunjukkan oleh terbentuknya zona bening. Selanjutnya koloni-koloni bakteri yang tumbuh diambil menggunakan ose kemudian digoreskan ke medium MRS agar miring dan diinkubasi pada suhu kamar selama 48 jam. Koloni BAL yang memiliki ukuran yang sangat kecil diambil menggunakan jarum preparat dan diinokulasikan ke dalam medium MRS cair.

Isolat BAL dimurnikan dengan metode goresan. Isolat BAL dalam kultur miring maupun kultur cair diambil menggunakan ose kemudian di goreskan ke atas medium MRS agar secara aseptik. Inkubasi pada suhu kamar selama 48 jam. Satu koloni yang yang terpisah diambil menggunakan ose dan di goreskan ke medium MRS agar miring. Isolat BAL dibuat stok dalam $10 \%$ skim milk dan $30 \%$ gliserol dengan perbandingan 1:1 dan di simpan pada suhu beku $-80^{\circ} \mathrm{C}$.

Kemampuan menghasilkan senyawa antibakteri terhadap Vibrio dilakukan dengan uji antagonis langsung (Bourouni et al., 2007) menggunakan metode paper disc diffusion agar. Isolat BAL ditumbuhkan dalam medium MRS cair, inkubasi pada suhu kamar selama 24 jam. Lima puluh mikroliter kultur isolat BAL dipipetkan ke atas kertas cakram steril (diameter $8 \mathrm{~mm}$ ) yang diletakkan di dalam cawan petri steril kemudian menggunakan pipet steril dipindahkan ke atas medium Nutrient Agar yang telah diinokulasi dengan bakteri uji (bakteri Vibrio). Bakteri Vibrio yang digunakan untuk uji ini adalah Vibrio harveyi, $V$. parahaemolyticus, $V$. alginolyticus dan $V$. anguilarum. Inkubasi pada suhu kamar selama 24 jam. Kertas cakram yang membentuk zona bening disekelilingnya menunjukkan adanya aktivitas penghambatan pertumbuhan Vibrio. Diameter zona bening yang terbentuk diukur dan digunakan untuk menentukan besarnya aktivitas penghambatan. Aktivitas antibakteri dihitung dengan rumus seperti yang digunakan oleh Sunaryanto dan Tarwadi (2015).

\section{HASIL DAN PEMBAHASAN}

BAL diisolasi dari intestinum udang penaeid yaitu udang windu dan 2 jenis udang putih yang ditangkap di perairan pantai Situbondo, Semarang dan Cilacap. Sampel udang hidup dipilih yang sehat (dicirikan dari kenampakan karapas dan kelengkapan alat geraknya). Udang 
dimatikan dengan teknik anestesi dingin. Sampel intestinum diambil secara aseptis menggunakan alat seksio dan pinset steril. Isolasi BAL dilakukan dengan teknik pourplate menggunakan medium MRS agar yang diperkaya dengan $\mathrm{CaCO}_{3}$. Koloni yang menghasilkan asam ditunjukkan oleh terbentuknya zona jernih di sekitar koloni (Gambar 1.). Zona jernih ini merupakan hasil reaksi asam yang diproduksi oleh koloni bakteri dengan $\mathrm{CaCO}_{3}$ yang ada pada medium isolasi. Hasil isolasi diperoleh total 224 isolat BAL yang terdiri dari 67 isolat udang windu (Penaeus monodon) dan 157 isolat dari 2 jenis udang putih (62 isolat dari intestinum Metapenaeu ensis dan 95 isolat dari intestinum Penaeus merguiensis). Hasil seleksi berdasarkan aktivitas antibakteri terhadap vibrio ditunjukkan pada Tabel 1 . Hasil ini sesuai dengan pernyataan Nikoskelainen et al., (2001) bahwa BAL merupakan mikroorganisme normal di dalam saluran pencernaan hewan yang sehat baik mamalia maupun hewan budidaya akuatik. Peneliti sebelumnya juga berhasil mengisolasi BAL dari saluran pencernaan udang windu hasil budidaya (Shakila et al., 2006), udang Vaname hasil budidaya (Vieira et al., 2013), ikan dan udang (Noordiana et al., 2013), kuruma shrimp (Marsupenaeus japonicus) (Maeda et al., 2014), Fenneropenaeus chinensis dan ikan Acanthogobius hasta (Sha et al.,
2016). Hasil-hasil penelitian ini menunjukkan bahwa BAL merupakan mikroorganisme saluran pencernaan udang. Berdasarkan hal ini maka BAL potensial dikembangkan sebagai probiotik untuk udang.

Berdasarkan jenis Vibrio yang dihambat didapatkan jumlah isolat $\mathrm{BAL}$ yang mampu menghambat $V$. harveyi, $V$. anguilarum, dan V. parahaemolyticus berturut-turut 59, 83 dan 66 (Tabel 2.). Sedangkan berdasarkan jumlah jenis Vibrio yang dihambat didapatkan jumlah isolat BAL yang mampu menghambat 3,2 , dan 1 jenis Vibrio uji berturut-turut adalah 51, 25 dan 11 (Tabel 2).

Aktivitas antibakteri merupakan salah satu karakter utama probiotik untuk mampu memproteksi inang dari infeskai pathogen didalam saluran cernanya. Salah satu kemampuan penghambatan pathogen adalah melalui produksi metabolit seperti asam organik (asam laktat dan asam asetat) (Suskovic et al., 2010). Kemampuan antibakteri asam organik terhadap Vibrio juga dibuktikan oleh Ricke, (2003) dan Mine \& Boopathy, (2011). Penelitian da Silva et al., (2013) secara in vitro membuktikan bahwa sodium asetat, sodium butirat, sodium sitrat,

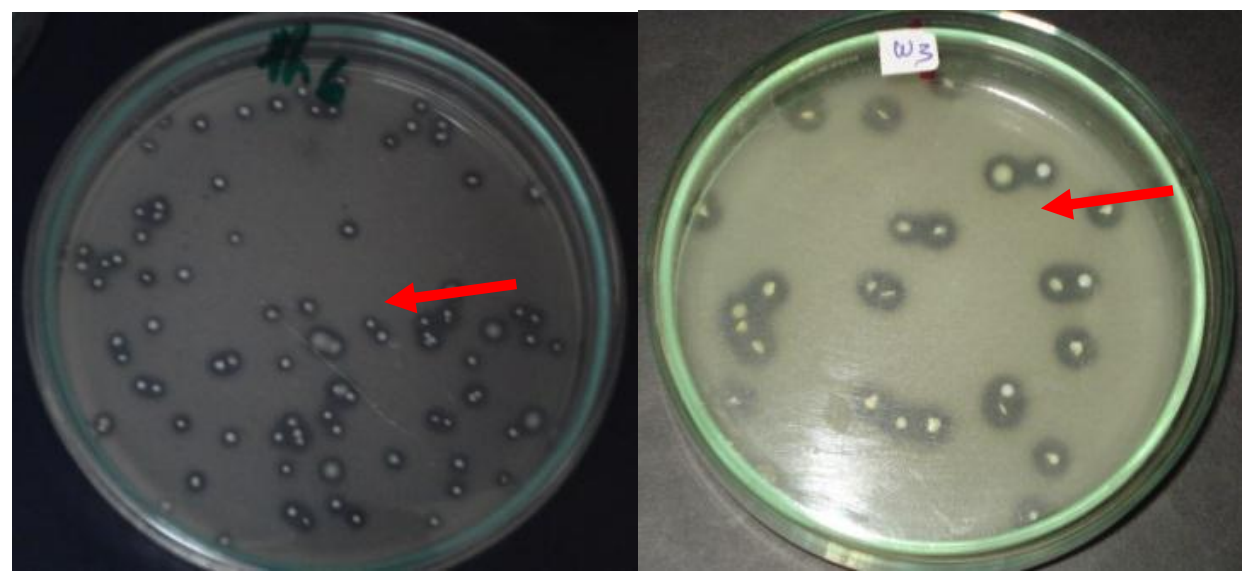

Gambar 1. Hasil isolasi BAL dari intestinum udang penaeid. Koloni yang membentuk zona jernih adalah koloni yang menghasilkan asam. Zona jernih berasal dari reaksi antara asam yang dihasilkan oleh koloni bakteri dengan $\mathrm{CaCO}_{3}$ yang ada di medium isolasi 
Tabel 1. Hasil seleksi isolat BAL intestinal udang penaeid yang memiliki aktivitas anti vibrio ( $\mathrm{mm}$ diameter zona hambat). Diameter paper disk $8 \mathrm{~mm}$ dan volume kultur yang diteteskan ke paper disk $50 \mu \mathrm{l}$.

\begin{tabular}{|c|c|c|c|c|c|c|c|}
\hline \multirow[b]{2}{*}{ No } & \multirow[b]{2}{*}{$\begin{array}{l}\text { Kode } \\
\text { isolat }\end{array}$} & \multicolumn{2}{|c|}{ V. harveyi } & \multicolumn{2}{|c|}{ V. anguilarum } & \multicolumn{2}{|c|}{ V. parahaemolyticus } \\
\hline & & $\begin{array}{l}\text { Diameter } \\
\text { zona } \\
\text { hambat } \\
(\mathrm{mm})\end{array}$ & $\begin{array}{l}\text { Aktivitas } \\
\text { anti } \\
\text { bakteri } \\
\left(\mathrm{ml} / \mathrm{mm}^{3}\right)\end{array}$ & $\begin{array}{c}\text { Diameter } \\
\text { zona } \\
\text { hambat } \\
(\mathrm{mm})\end{array}$ & $\begin{array}{l}\text { Aktivitas } \\
\text { anti } \\
\text { bakteri } \\
\left(\mathrm{ml} / \mathrm{mm}^{3}\right)\end{array}$ & $\begin{array}{l}\text { Diameter } \\
\text { zona } \\
\text { hambat } \\
(\mathrm{mm})\end{array}$ & $\begin{array}{c}\text { Aktivitas anti } \\
\text { bakteri } \\
\left(\mathrm{ml} / \mathrm{mm}^{3}\right)\end{array}$ \\
\hline 1 & M4.1 & 0 & 0 & 16 & 5756,7 & 8 & 732,7 \\
\hline 2 & M4.2 & 12 & 2826,0 & 20 & 9524,7 & 16 & 5756,7 \\
\hline 3 & M6.1 & 12 & 2826,0 & 20 & 9524,7 & 12 & 2826,0 \\
\hline 4 & M6.2 & 9 & 1177,5 & 19 & 8504,2 & 11 & 2224,2 \\
\hline 5 & M6.3 & 12 & 2826,0 & 20 & 9524,7 & 0 & 0 \\
\hline 6 & M6.4 & 12 & 2826,0 & 20 & 9524,7 & 0 & 0 \\
\hline 7 & MP.3 & 12 & 2826,0 & 20 & 9524,7 & 10 & 1674,7 \\
\hline 8 & MP.4 & 13 & 3480,2 & 18 & 7536,0 & 12 & 2826,0 \\
\hline 9 & P2.10 & 0 & 0 & 17 & 6620,2 & 0 & 0 \\
\hline 10 & P2.11.1 & 0 & 0 & 20 & 9524,7 & 11 & 2224,2 \\
\hline 11 & P2.11.2 & 0 & 0 & 12 & 2826,0 & 10 & 1674,7 \\
\hline 12 & P2.11.3 & 15 & 4945,5 & 12 & 2826,0 & 10 & 1674,7 \\
\hline 13 & P6.14 & 6 & 0,0 & 15 & 4945,5 & 10 & 1674,7 \\
\hline 14 & P6.15 & 14 & 4186,7 & 20 & 9524,7 & 0 & 0 \\
\hline 15 & P6.3 & 0 & 0 & 15 & 4945,5 & 10 & 1674,7 \\
\hline 16 & P6.4 & 0 & 0 & 15 & 4945,5 & 10 & 1674,7 \\
\hline 17 & W6.13 & 0 & 0 & 16 & 5756,7 & 8 & 732,7 \\
\hline 18 & M3.2 & 0 & 0 & 24 & 14130,0 & 10 & 1674,7 \\
\hline 19 & M7.1 & 10 & 1674,7 & 18 & 7536,0 & 12 & 2826,0 \\
\hline 20 & M7.2 & 10 & 1674,7 & 15 & 4945,5 & 12 & 2826,0 \\
\hline 21 & M7.3 & 10 & 1674,7 & 17 & 6620,2 & 12 & 2826,0 \\
\hline 22 & P.6.10 & 0 & 0 & 19 & 8504,2 & 0 & 0 \\
\hline 23 & P.6.12 & 12 & 2826,0 & 15 & 4945,5 & 0 & 0 \\
\hline 24 & P6.11 & 0 & 0 & 11 & 2224,2 & 0 & 0 \\
\hline 25 & P6.13 & 11 & 2224,2 & 10 & 1674,7 & 7 & 340,2 \\
\hline 26 & P6.14 & 13 & 3480,2 & 12 & 2826,0 & 10 & 1674,7 \\
\hline 27 & P6.15 & 14 & 4186,7 & 10 & 1674,7 & 7 & 340,2 \\
\hline 28 & P6.5 & 10 & 1674,7 & 17 & 6620,2 & 11 & 2224,2 \\
\hline 29 & P6.6 & 0 & 0 & 14 & 4186,7 & 0 & 0 \\
\hline 30 & P6.7.1 & 11 & 2224,2 & 17 & 6620,2 & 11 & 2224,2 \\
\hline 31 & P6.7.2 & 0 & 0 & 19 & 8504,2 & 0 & 0 \\
\hline 32 & P6.8 & 11 & 2224,2 & 17 & 6620,2 & 12 & 2826,0 \\
\hline 33 & P6.9 & 14 & 4186,7 & 20 & 9524,7 & 0 & 0 \\
\hline 34 & Pa.1.1 & 12 & 2826,0 & 8 & 732,7 & 0 & 0 \\
\hline 35 & Pa.1.2 & 0 & 0 & 11 & 2224,2 & 0 & 0 \\
\hline 36 & Pa.1.3 & 0 & 0 & 14 & 4186,7 & 0 & 0 \\
\hline 37 & PB. 1.4 & 0 & 0 & 15 & 4945,5 & 0 & 0 \\
\hline 38 & PB.9.3 & 12 & 2826,0 & 12 & 2826,0 & 7 & 340,2 \\
\hline 39 & PB 1.1 & 0 & 0 & 13 & 3480,2 & 0 & 0 \\
\hline 40 & PB 1.2 & 0 & 0 & 15 & 4945,5 & 0 & 0 \\
\hline 41 & PB9.1 & 0 & 0 & 10 & 1674,7 & 0 & 0 \\
\hline 42 & PB9. 2 & 0 & 0 & 0 & 0 & 0 & 0 \\
\hline 43 & SS 1 & 9 & 1177,5 & 8 & 732,7 & 13 & 3480,2 \\
\hline 44 & SS1.1 & 8 & 732,7 & 9 & 1177,5 & 11 & 2224,2 \\
\hline 45 & SS2 & 9 & 1177,5 & 9 & 1177,5 & 12 & 2826,0 \\
\hline 46 & SS2.1 & 8 & 732,7 & 8 & 732,7 & 9 & 1177,5 \\
\hline 47 & SS3 & 9 & 1177,5 & 8 & 732,7 & 13 & 3480,2 \\
\hline 48 & SS3.1 & 10 & 1674,7 & 8 & 732,7 & 13 & 3480,2 \\
\hline 49 & SS4 & 8 & 732,7 & 11 & 2224,2 & 12 & 2826,0 \\
\hline 50 & SS4.1 & 12 & 2826,0 & 11 & 2224,2 & 13 & 3480,2 \\
\hline 51 & SS5 & 9 & 1177,5 & 10 & 1674,7 & 9 & 1177,5 \\
\hline
\end{tabular}




\begin{tabular}{|c|c|c|c|c|c|c|c|}
\hline \multirow[b]{2}{*}{ No } & \multirow[b]{2}{*}{$\begin{array}{l}\text { Kode } \\
\text { isolat }\end{array}$} & \multicolumn{2}{|c|}{ V. harveyi } & \multicolumn{2}{|c|}{ V. anguilarum } & \multicolumn{2}{|c|}{ V. parahaemolyticus } \\
\hline & & $\begin{array}{l}\text { Diameter } \\
\text { zona } \\
\text { hambat } \\
(\mathrm{mm})\end{array}$ & $\begin{array}{l}\text { Aktivitas } \\
\text { anti } \\
\text { bakteri } \\
\left(\mathrm{ml} / \mathrm{mm}^{3}\right)\end{array}$ & $\begin{array}{l}\text { Diameter } \\
\text { zona } \\
\text { hambat } \\
(\mathrm{mm})\end{array}$ & $\begin{array}{l}\text { Aktivitas } \\
\text { anti } \\
\text { bakteri } \\
\left(\mathrm{ml} / \mathrm{mm}^{3}\right)\end{array}$ & $\begin{array}{l}\text { Diameter } \\
\text { zona } \\
\text { hambat } \\
(\mathrm{mm})\end{array}$ & $\begin{array}{c}\text { Aktivitas anti } \\
\text { bakteri } \\
\left(\mathrm{ml} / \mathrm{mm}^{3}\right)\end{array}$ \\
\hline 52 & SS5.1 & 8 & 732,7 & 8 & 732,7 & 9 & 1177,5 \\
\hline 53 & S56 & 17 & 6620,2 & 11 & 2224,2 & 17 & 6620,2 \\
\hline 54 & SS6.1 & 11 & 2224,2 & 8 & 732,7 & 11 & 2224,2 \\
\hline 55 & SS6.2 & 9 & 1177,5 & 8 & 732,7 & 11 & 2224,2 \\
\hline 56 & SS6.3 & 10 & 1674,7 & 8 & 732,7 & 11 & 2224,2 \\
\hline 57 & w6.19 & 0 & 0 & 15 & 4945,5 & 8 & 732,7 \\
\hline 58 & W6.20 & 0 & 0 & 14 & 4186,7 & 8 & 732,7 \\
\hline 59 & B2.4.2 & 9 & 1177,5 & 9 & 1177,5 & 12 & 2826,0 \\
\hline 60 & B2.4.3 & 9 & 1177,5 & 11 & 2224,2 & 12 & 2826,0 \\
\hline 61 & B2.4.4 & 9 & 1177,5 & 9 & 1177,5 & 12 & 2826,0 \\
\hline 62 & BB. 1 & 8 & 732,7 & 8 & 732,7 & 10 & 1674,7 \\
\hline 63 & $\mathrm{BB} 1$ & 12 & 2826,0 & 8 & 732,7 & 0 & 0 \\
\hline 64 & BBC. 1 & 10 & 1674,7 & 10 & 1674,7 & 8 & 732,7 \\
\hline 65 & BBC.1.1 & 10 & 1674,7 & 10 & 1674,7 & 9 & 1177,5 \\
\hline 66 & BBC. 8 & 11 & 2224,2 & 12 & 2826,0 & 9 & 1177,5 \\
\hline 67 & BBC. 9 & 0 & 0 & 8 & 732,7 & 8 & 732,7 \\
\hline 68 & BBF.12 & 0 & 0 & 8 & 732,7 & 12 & 2826,0 \\
\hline 69 & BBF.3 & 9 & 1177,5 & 10 & 1674,7 & 8 & 732,7 \\
\hline 70 & BFC.7 & 9 & 1177,5 & 8,5 & 948,5 & 11 & 2224,2 \\
\hline 71 & BKC. 5 & 0 & 0 & 9 & 1177,5 & 12 & 2826,0 \\
\hline 72 & BKC. 6 & 11 & 2224,2 & 8 & 732,7 & 17 & 6620,2 \\
\hline 73 & BKFC.1 & 12 & 2826,0 & 10 & 1674,7 & 12 & 2826,0 \\
\hline 74 & BKFC. 1 & 8 & 732,7 & 9 & 1177,5 & 0 & 0 \\
\hline 75 & BKFC.2 & 10 & 1674,7 & 12 & 2826,0 & 8 & 732,7 \\
\hline 76 & BKFC.2.1 & 9 & 1177,5 & 8 & 732,7 & 8 & 732,7 \\
\hline 77 & PS 12 & 9 & 1177,5 & 10 & 1674,7 & 14 & 4186,7 \\
\hline 78 & PS 14 & 13 & 3480,2 & 9 & 1177,5 & 14 & 4186,7 \\
\hline 79 & PS20.2 & 10 & 1674,7 & 9 & 1177,5 & 12 & 2826,0 \\
\hline 80 & PS4.2 & 13 & 3480,2 & 13 & 3480,2 & 17 & 6620,2 \\
\hline 81 & PS6.2 & 12 & 2826,0 & 11 & 2224,2 & 15 & 4945,5 \\
\hline 82 & PS9 & 12 & 2826,0 & 12 & 2826,0 & 18 & 7536,0 \\
\hline 83 & WC.8 & 11 & 2224,2 & 9 & 1177,5 & 17 & 6620,2 \\
\hline 84 & WFC.2 & 9 & 1177,5 & 9 & 1177,5 & 12 & 2826,0 \\
\hline
\end{tabular}

Tabel 2. Jumlah isolat BAL yang aktif terhadap Vibrio

\begin{tabular}{cccccc}
\hline & Jenis Vibrio uji yang dihambat & \multicolumn{3}{c}{ Jumlah jenis Vibrio yang dihambat } \\
\hline V. harveyi & V. anguilarum & V. parahaemolyticus & 3 & 2 & 1 \\
59 & 83 & 66 & 51 & 25 & 11 \\
\hline
\end{tabular}

sodium format, sodium laktat dan sodium propionat secara in vitro mampu menghambat Vibrio harveyi, $V$. alginolyticus, dan V. anguillarum. Hasil penelitian yang lain terkait dengan pemanfaatan asam sebagai agensia antibakteri terhadap Vibrio membuktikan bahwa aplikasi asam organik ini secara nyata mampu meningkatkan resistensi udang vaname (Romano et al., 2015) dan Penaeus monodon ( $\mathrm{Ng}$ et al., 2015) terhadap infeksi vibrio harveyi. Kemampuan BAL terpilih menghasilkan asam organik ini membawa kepada kemampuan fungsional sebagai probiotik untuk mengendalikan komunitas mikroorganisme di dalam intestinum. Di dalam intestinum tumbuh beragam mikroorganisme yang dapat bersifat merugikan udang. Bakteri pathogen seperti Vibrio potensial menyebabkan infeksi yang mematikan bagi udang. Beberapa 
penelitian menunjukkan keganasan Vibrio terhadap udang Vannamei (SotoRodriguez et al., 2010 ;Heenatigala \& Fernando, 2016 ; Hong et al., 2016). Vibrio juga diketahui sebagai agensia penyebab penyakit early mortality syndrome (EMS) atau "acute hepatopancreatic necrosis disease" (AHPND) (De Schryver et al., 2014). Toksisitas asam organik disebabkan oleh gangguan homeostasis $\mathrm{pH}$ seluler: asam yang terprotonasi berdifusi ke dalam sel di mana ia mengalami de-protonasi dan mengubah baik $\Delta \mathrm{pH}$ dan $\Delta \psi$. (Zhitnitsky, et al., 2017). Proses ini membutuhkan energi ATP, sehingga menyebabkan deplesi energi seluler. Penurunan $\mathrm{pH}$ sitoplasma juga akan menyebabkan denaturasi protein dan DNA, dan meninmbulkan gangguan pada proses fisiologi sel. Selain itu asam laktat juga dapat berinterferensi dengan struktur membran sitoplasma dan protein membran sehingga mengganggu kinerja membran sitoplasma (Ricke, 2003). Alakomi et al., (2000) dalam penelitiannya melaporkan bahwa asam laktat baik dalam bentuk terdisosiasi atau tidak terdisosiasi dapat menyebabkan disintegrasi outer membrane dan LPS.

Berdasarkan hasil penelitian ini didapatkan isolat-isolat BAL yang potensial untuk dikembangkan sebagai probiotik. Hal ini karena isolat BAL yang diperoleh menunjukkan kemampuan untuk menghambat pertumbuhan Vibrio pathogen. Isolat potensial ini selanjutnya perlu diseleksi lebih lanjut menggunakan kriteria seleksi probiotik baik secara in vitro maupun in vivo.

\section{DAFTAR PUSTAKA}

Alakomi, H. L., Skytta, E., Saarela, M., Mattila-Sandholm, T., Latva-Kala, K. Aguirre-Guzmán, G., M., Lara-Flores, J. G., Sánchez-Martínez, A. I. and Campa-Córdova, 2012, The Use of Probiotics in Aquatic Organisms: A review, African Journal of Microbiology Research, $6: 4845-4857$.

Balcazar, J. L., de Blas, I., Ruiz-Zarzuela, I., Cunningham, D., Vendrell, D., Mu'zquiz, J. L., 2006, The Role of Probiotics in Aquaculture, Veterinary Microbiology, $114: 173-186$.
Balcázar, J., Decamp, O., Vendrell, D., De Blas, I. and Ruiz-Zarzuela, I., 2006, Health and Nutritional Properties of Probiotics in Fish and Shellfish, Microbial Ecology in Health and Disease, 18 : 6570.

Bogale, A. T. and Prapulla, S.G., 2015, Studies on Amylase from Probiotic Lactic Acid Bacteria, International Journal of Modern Chemistry and Applied Science, 2(4) : 211-214.

Bourouni, O. C., Bour, M. E., Mraouna, R., Abdennaceur, H., Boudabous, A., 2007, Preliminary Selection Study of Potential Probiotic Bacteria from Aquacultural Area in Tunisia, Annals of Microbiology, $57: 185-190$.

Cruz, P.M., Ibanez, A. L., MonroyHermosillo, O. A., and Saad, H. C. R., 2012, Use of Probiotics in Aquaculture, ISRN Microbiology, Article ID 916845, 13 pages, http://dx.doi.org/10.5402/2012/916845

da Silva, B.C., Vieira, F.N., Mouriño, J.L.P., Ferreira, G.S., Seiffert, W.Q., 2013, Salts of Organic Acids Selection by Multiple Characteristics for Marine Shrimp Nutrition, Aquaculture, 384-387 : 104110.

De Schryver P, Defoirdt T, Sorgeloos P (2014) Early Mortality Syndrome Outbreaks: A Microbial Management Issue in Shrimp Farming? PLOS Pathogen 10(4): e1003919.

https://doi.org/10.1371/journal.ppat.10 03919

Drancourt, M. and Raoult, D., 2005, Sequence-Based Identification of New Bacteria: a Proposition for Creation of an Orphan Bacterium Repository, Journal of Clinical Microbiology., 43 (9): 4311-4315.

Farzanfar, A., 2006, The use of Probiotic in Shrimp Aquaculture, FEMS Immunology \& Medical Microbiology 48:149-158.

Heenatigala, P. P. M. \& Fernando, M. U. L., 2016, Occurrence of Bacteria Species Responsible for Vibriosis in Shrimp Pond Culture Systems in Sri Lanka and Assessment of the Suitable Control Measures, Sri Lanka Journal of Aquatic Science, $21(1): 1-17$.

Hong, X. P., XU, D., Zhuo, Y., Liu H. Q., LU, L. Q., 2016, Identification and pathogenicity of Vibrio 
parahaemolyticus isolates and immune responses of Penaeus (Litopenaeus) vannamei (Boone), Journal of Fish Disease, 39(9):1085-1097..

Kosin, B. and Rakshit, S. K., 2006, Microbial and Processing Criteria for Production of Probiotics: A Review, Food Technology and Biotechnology, 44 (3) : 371-379.

Ljungh, A, and Wadström, T., 2006, Lactic Acid Bacteria as Probiotics, Current Issues in Intestinal Microbiology, 7(2) : 73-89.

Maeda, M. 1., Shibata, A., Biswas, G., Korenaga, H., Kono, T., Itami, T., Sakai, M., 2014, Isolation of Lactic Acid Bacteria from Kuruma Shrimp (Marsupenaeus japonicus) Intestine and Assessment of Immunomodulatory Role of a Selected Strain as Probiotic, Marine Biotechnology (NY), 16(2) : 18192.

Mine, S., \& Boopathy, R., 2011, Effect of organic acids on shrimp pathogen, Vibrio harveyi, Current Microbiology, 63(1):1-7.

Ng, W., Koh, C., Teoh, C., Romano, N., 2015, Farm-Raised Tiger Shrimp, Penaeus Monodon, Fed Commercial Feeds With Added Organic Acids Showed Enhanced Nutrient Utilization, Immune Response And Resistance To Vibrio Harveyi Challenge, Aquaculture, 449 : 69-77.

Nikoskelainen, S., Salminen, S., Bylund, G., Ouwehand, A.C., 2001a., Characterization of the Properties of Human and Dairy Derived Probiotics for Prevention of Infectious Diseases in Fish. Applied and Environmental Microbiology, 67 : 2430-2435.

Noordiana, N., Fatimah, A. B. and Mun, A. S., 2013, Antibacterial Agents Produced by Lactic Acid Bacteria Isolated from Threadfin Salmon and Grass Shrimp, International Food Research Journal, 20(1) : 117-124.

Rattanachaikunsopon, P., and Phumkhachorn, P., 2010, Lactic Acid Bacteria : their Antimicrobial Compounds and their Uses in Food Production, Annals of Biological Research, $1: 218-228$.

Ricke, S. C., 2003, Perspectives on the Use of Organic Acids and Short Chain Fatty
Acids as Antimicrobials, Poultry Science, 82 : 632-639.

Romano, N., Koh, C., Ng, W. K., 2015, Dietary Microencapsulated Organic Acids Blend Enhances Growth, Phosphorus Utilization, Immune Response, Hepatopancreatic Integrity and Resistance Against Vibrio harveyi in White Shrimp, Litopenaeus vannamei, Aquaculture, 435 : 228-236.

Sha, Y., Wang, L., Liu, M., Jiang, K., Xin, F., Wang, B., 2016, Effects of Lactic Acid Bacteria and the Corresponding Supernatant on the Survival, Growth Performance, Immune Response and Disease Resistance of Litopenaeus vannamei, Aquaculture, $452: 28-36$.

Shakila, R. J., Saravanakumar, R., Vyla, S. A. P., Jeyasekaran, G., Jasmine, G. I., 2006. Antagonistic Activity of the Gut Microflora Isolated from Farmed Tiger Shrimp (Penaeus monodon), Asian Fisheries Science, 19 : 247-255.

Soto-Rodriguez, S. A., Gomez-Gil, B., Lozano, R., 2010, 'Bright-red' syndrome in Pacific white shrimp Litopenaeus vannamei is caused by Vibrio harveyi, Diseases Of Aquatic Organisms, 92: 1119.

Sunaryanto, R. dan Tarwadi, 2015, Isolasi dan Karakterisasi Bakteriosin yang Dihasilkan oleh oleh lactobacillus lactis dari Sedimen Laut, JPB Kelautan dan Perikanan, 10 (1):11-18.

Suskovic, J., Kos, B., Beganovic, J., Pavunc, A. L., Habjanic, K., Matosic, S., 2010, Antimicrobial Activity-the Most Important Property of Probiotic and Starter Lactic, Food Technology and Biotechnology, 48 : 296-307.

Vesterlund, S., Karp, M., Salminen, S. and Ouwehand, A. C., 2006, Staphylococcus aureus Adheres To Human Intestinal Mucus but can be Displaced by Certain Lactic Acid Bacteria. Microbiology, 152 : 18191826.

Vieira, F. P., Jatobá A., Mouriño, J. L. P., Vieira, E. A., Soares, M., da Silva, B. C., Seiffert, W. Q., Martins, M. L. and Vinatea, L. A., 2013, In vitro selection of Bacteria with Potential for Use as Probiotics in Marine Shrimp Culture, Pesquisa Agropecuária Brasileira, 48(8) :998-1004. 
Zhitnitsky, D., Rose, J., \& Lewinson, O. (2017). The highly synergistic, broad spectrum, antibacterial activity of organic acids and transition metals. Scientific Reports, 7. 44554. http://doi.org/10.1038/srep 44554
Zhou, X., Wang, Y., 2003. Probiotic in aquaculture-Benefits to the Health, Technological Applications and Safety, dalam Health and Environment in Aquaculture, E. Carvalho (ed.), InTech Europe, Croatia. p.215-226. 